\title{
AKIBAT HUKUM BAGI NOTARIS DALAM PEMBUATAN AKTA JAMINAN FIDUSIA PASCA TERBITNYA PUTUSAN MAHKAMAH KONSTITUSI NOMOR 18/PUU-XVII/2019 TENTANG EKSEKUSI JAMINAN FIDUSIA
}

\author{
Zidna Aufima ${ }^{1}$
}

\begin{abstract}
Post Release Constitutional Court Decision Number 18/PUU-XVII/2019 about Fiduciary Collateral Execute raises legal effect for Notary in making Fiduciary Collateral Contract. By Using statute approach dan conceptual approach. the result of this study showed that Notary must revise fiduciary collateral contract all this time created in a way Notary must add and explain default clause in detail consist of definition, shapes, how and when default. Notary also must enter voluntary surrender clause about object of fiduciary collateral consist of how does fiduciary collateral giver unwilling to hand over fiduciary collateral voluntarily and how does fiduciary collateral receiver if will do force effort. Purpose from Notary must add and explain default clause in detail and enter voluntary surrender clause about object of fiduciary collateral in fiduciary collateral contract is to create certainty of law and justice for Creditor as Fiduciary Giver and Debtor as Fiduciary Receiver, because fiduciary collateral contract must granting legal protective for parties and object that become fiduciary collateral in fiduciary collateral contract.

Keywords: Legal Effect, Constitutional Court Decision, Notary, Fiduciary Collateral Contract, Default, Fiduciary Collateral Execute, Legal Protective, Creditor, Debtor.
\end{abstract}

\begin{abstract}
Abstrak
Pasca terbitnya Putusan Mahkamah Konstitusi Nomor 18/PUU-XVII/2019 tentang Eksekusi Jaminan Fidusia menimbulkan akibat hukum bagi notaris dalam pembuatan akta jaminan fidusia. Metode yang digunakan adalah statute approach dan conceptual approach. Hasil penelitian ini dapat diketahui bahwa notaris harus mengubah akta jaminan fidusia yang selama ini dibuat dengan cara notaris harus menambahkan dan memperjelas klausula wanprestasi atau cidera janji secara terperinci yang terdiri dari definisi, bentuk-bentuk, bagaimana dan kapan wanprestasi atau cidera janji. Notaris juga harus mencantumkan klausula penyerahan sukarela tentang obyek jaminan fidusia yang terdiri dari bagaimana pemberi jaminan fidusia tidak bersedia menyerahkan jaminan fidusia secara sukarela dan bagaimana penerima jaminan fidusia apabila akan melakukan upaya paksa. Tujuan dari Notaris harus menambahkan dan memperjelas klausula wanprestasi atau cidera janji secara terperinci serta mencantumkan klausula penyerahan sukarela tentang obyek jaminan fidusia dalam akta jaminan fidusia adalah untuk menciptakan kepastian hukum dan keadilan bagi kreditor selaku Penerima
\end{abstract}

\footnotetext{
${ }^{1}$ Magister Kenotariatan, Fakultas Hukum, Universitas Airlangga, zidna.aufima2016@fh.unair.ac.id
} 
Fidusia dan Debitor selaku Pemberi Fidusia, karena akta jaminan fidusia wajib mewujudkan perlindungan hukum bagi para pihak dan obyek yang menjadi jaminan fidusia dalam akta jaminan fidusia.

Kata Kunci : Akibat Hukum, Putusan Mahkamah Konstitusi, Notaris, Akta Jaminan Fidusia, Wanprestasi, Eksekusi Jaminan Fidusia, Perlindungan Hukum, Kreditor, Debitor.

\section{A. Latar Belakang}

Pada era globalisasi, kebutuhan manusia terus meningkat dikarenakan ilmu pengetahuan dan teknologi semakin meningkat. Perkembangan ilmu pengetahuan dan teknologi pada era globalisasi ini membawa dampak tidak hanya sebatas kebutuhan primer namun juga terhadap beberapa segi kehidupan di Indonesia baik di bidang sosial, ekonomi, budaya dan lain-lain. Pada perkembangan di bidang ekonomi, menyebabkan membentuk masyarakat melakukan pengembangan di bidang bisnis. Berbagai macam bisnis yang dapat dilakukan oleh manusia untuk kelangsungan hidupnya yaitu seperti jual beli atau perdagangan, menjadi pengusaha kecil maupun pengusaha yang mendirikan perusahaan sendiri. Perkembangan bisnis saat ini juga turut mengalami perkembangan. Berikut merupakan dampak perkembangan dalam bidang ekonomi adalah ${ }^{2}$ :

1. Pertumbuhan ekonomi yang semakin tinggi

2. Terjadinya industrialisasi

3. Produktifitas yang semakin meningkat

4. Persaingan usaha baik dari dalam maupun dari luar negeri

5. Investasi dan Reinvestasi yang berlangsung secara besar-besaran yang dapat meningkatkan produktifitas ekonomi

6. Persaingan dalam dunia kerja yang menuntut pekerjaan untuk selalu menambah skill dan pengetahuan yang dimiliki

Lembaga keuangan adalah badan usaha yang mempunyai kekayaan dalam bentuk aset keuangan. Dalam kegiatan usahanya lembaga keuangan lebih menekankan pada fungsi keuangan yaitu jasa keuangan pembiayaan dan jasa keuangan bukan pembiayaan. Istilah lembaga keuangan lebih luas ruang lingkupnya daripada istilah lembaga pembiayaan. Dengan aset kekayaan yang dimiliki lembaga keuangan, aset tersebut digunakan untuk menjalankan usaha dibidang jasa keuangan baik penyediaan dana untuk membiayai usaha produktif dan kebutuhan konsumtif maupun jasa keuangan bukan pembiayaan.

\footnotetext{
${ }^{2}$ Andy Hartanto, (2015), Hukum Jaminan dan Kepailitan, Surabaya: Laksbang Yustisia, h.5.
} 
Sedangkan lembaga pembiayaan adalah badan usaha yang melakukan kegiatan pembiayaan dalam bentuk penyediaan dana atau barang modal dengan tidak menarik dana langsung dari masyarakat. ${ }^{3}$ Kegiatan lembaga pembiayaan dapat dilakukan oleh perusahaan pembiayaan, yang termasuk perusahaan pembiayaan adalah badan usaha diluar bank dan di luar lembaga keuangan. ${ }^{4}$ Berdasarkan Keputusan Menteri Keuangan Republik Indonesia (selanjutnya disebut KepKemenkeu RI) Nomor 448/KMK.017/2000 lembaga pembiayaan yang djalankan oleh perusahaan pembiayaan adalah sewa guna usaha (leasing), anjak piutang, usaha kartu kredit, dan pembiayaan konsumen.

Leasing berasal dari kata Lease yang berarti sewa menyewa, sehingga leasing merupakan bentuk derivatif dari sewa menyewa. Tetapi kemudian dalam dunia bisnis berkembanglah sewa menyewa dalam bentuk khusus yang disebut leasing dan dalam bahasa indonesia leasing sering diistilahkan dengan sewa guna usaha. Lessor sebagai pihak yang memberikan pembiayaan kepada pihak yang membutuhkan, Lessee adalah pihak yang memerlukan barang modal yang dibiayai oleh Lessor dan Supplier merupakan pihak yang menyediakan barang modal yang menjadi obyek leasing. ${ }^{5}$ Secara umum jenis-jenis leasing ini bisa dibedakan menjadi dua kelompok yaitu Financial Lease dan Operating Lease. Financial Lease adalah sewa dimana kepemilikan barang tersebut berpindah dari pemberi sewa kepada penyewa. Apabila dalam masa akhir sewa, pihak penyewa tidak melunasi sewanya barang tersebut tetapi merupakan milik pemberi sewa dan jika akhir sewa, pihak penyewa dapat melunasi sewanya barang tersebut akan menjadi milik penyewa. Sedangkan Operating Lease adalah sewa menyewa barang hanya untuk mendapatkan manfaat barang yang disewanya, tetapi barang tersebut tetap milik pemberi sewa. ${ }^{6}$

Berdasarkan pasal 1 ayat (1) Peraturan Presiden Nomor 9 tahun 2009 tentang Lembaga Pembiayaan, lembaga pembiayaan (leasing) adalah badan usaha yang melakukan kegiatan pembiayaan dalam bentuk penyediaan dana atau barang modal. Dan dalam Pasal 1 angka 5 Peraturan Presiden Nomor 9 tahun 2009 tentang Lembaga Pembiayaan dijelaskan bahwa kegiatan pembiayaan dilaksanakan dalam bentuk penyediaan barang modal baik secara sewa guna usaha dengan hak opsi (finance lease) maupun sewa guna usaha tanpa hak opsi (operating lease) untuk digunakan oleh penyewa guna usaha (lessee) selama jangka waktu tertentu berdasarkan pembayaran secara angsuran.

${ }^{3}$ Abdulkadir Muhammad dan Rilda Murniati, (2000), Segi Hukum Lembaga Keuangan dan Pembiayaan, Bandung: Citra Aditya Bakti, h.8.

${ }^{4}$ Abdulkadir Muhammad dan Rilda Murniati, Op.Cit., h. 18.

5 Munir Fuady, (1999), Hukum tentang Pembiayaan Dalam Teori dan Praktik (Leasing, Factoring, Modal Ventura, Pembiayaan Konsumen, Kartu Kredit), Bandung: Citra Aditya Bakti, h. 78.

\footnotetext{
${ }^{6}$ Edy P Soekadi, (1990), Mekanisme Leasing, Jakarta: Ghalia Indonesia, h. 20.
} 
Pembiayaan konsumen sebagai salah satu bentuk bisnis pembiayaan bersumber dari berbagai ketentuan hukum, baik perjanjian maupun perundang-undangan. ${ }^{7}$ Perjanjian pembiayaan konsumen dibuat berdasarkan asas kebebasan berkontrak yang diatur dalam Pasal 1338 Burgelijk Wetboek. Asas kebebasan berkontrak para pihak yang memuat rumusan kehendak berupa hak dan kewajiban dari perusahaan pembiayaan konsumen sebagai pihak penyedia dana (fund lender), dan konsumen sebagai pihak pengguna dana (fund over). Hubungan antara pihak kreditur dengan debitur adalah hubungan kontraktual dalam hal ini perjanjian pembiayaan konsumen. Apabila debitur tidak tepat waktu dalam melaksanakan kewajibannya maka debitur wanprestasi, adapun bentuk-bentuk wanprestasi yaitu: ${ }^{8}$

1. Tidak melaksanakan prestasi sama sekali

2. Melaksanakan prestasi, tetapi tidak sebagaimana mestinya

3. Melaksanakan prestasi, tetapi tidak tepat pada waktunya

4. Melaksanakan perbuatan yang dilarang dalam perjanjian

Dalam praktik, Leasing belum tentu berjalan dengan lancar pada saat perjanjian leasing berlangsung. Permasalahan tersebut seperti Lessee yang lalai melakukan kewajibannya untuk membayar angsuran atau disebut wanprestasi. Contoh konkritnya yaitu Aprilia Dewi dan Suri Agung Prabowo selaku pemohon telah melakukan perjanjian pembiayaan multiguna dengan PT. Astra Sedaya Finance atas penyediaan dana pembelian 1 (satu) unit mobil mewah Toyota Alphard V Model 2.4 A/T 2004. Sesuai perjanjian yang telah disepakati, Pemohon berkewajiban membayar utang kepada PT. Astra Sedaya Finance senilai Rp. 222.696.000,- (dua ratus dua puluh dua juta enam ratus sembilan puluh enam ribu rupiah) dengan cicilan selama 35 (tiga puluh lima bulan) terhitung sejak tanggal 18 November 2016.

Selama tanggal 18 November 2016 sampai tanggal 18 November 2017, Pemohon telah membayar angsuran secara taat. Namun, pada tanggal 10 November 2017, pihak PT. Astra Sedaya Finance mengirim perwakilan untuk mengambil kendaraan Pemohon dengan dalil wanprestasi. Pemohon mengalami tindakan pengambilan paksa mobil mewah Toyota Alphard V Model 2.4 A/T 2004 oleh PT. Astra Sedaya Finance.

Atas perlakuan tersebut, pemohon mengajukan surat pengaduan atas tindakan yang dilakukan oleh perwakilan PT. Astra Sedaya Finance. Namun pengajuan tersebut tidak ditanggapi hingga ada beberapa perlakuan yang tidak menyenangkan selanjutnya. Menerima perlakuan tersebut, Pemohon berupaya mengambil langkah hukum dengan mengajukan perkara ke Pengadilan Negeri Jakarta Selatan pada tanggal 24 April 2018 dengan gugatan perbuatan melawan hukum dengan nomor registrasi perkara

${ }^{7}$ Abdulkadir Muhammad dan Rilda Murniati, Op.Cit., h. 214.

8 Muhammad Syaifuddin, (2012), Hukum Kontrak Memahami Kontrak dalam Perspektif Filsafat, Teori, Dogmatik, dan Praktik Hukum (Seri Pengayaan Hukum Perikatan), Bandung: Mandar Maju, h. 338. 
345/PDT.G/2018/PN.Jkt.Sel. Pengadilan Negeri Jakarta Selatan pun mengabulkan gugatan Pemohon dengan menyatakan bahwa PT. Astra Sedaya Finance telah melakukan perbuatan melawan hukum. Namun pada tanggal 11 Januari 2018, PT. Astra Sedaya Finance melakukan penarikan paksa kendaraan Pemohon dengan disaksikan pihak kepolisian.

Atas perlakukan tersebut, Pemohon mengajukan permohonan uji materil ketentuan Pasal 15 ayat (2), ayat (3) Undang-Undang Nomor 42 Tahun 1999 yang mengatur mengenai kekuatan eksekutorial sertiifikat fidusia dan parate eksekusi ke Mahkamah Konstitusi. Pemohon mendalilkan bahwa ketentuan Pasal 15 ayat (2), ayat (3) UndangUndang Nomor 42 Tahun 1999 bertentangan dengan Pasal 1 ayat (3), Pasal 27 ayat (1), Pasal 28D ayat (1), Pasal 28G ayat (1) dan Pasal 28H ayat (4) UUD 1945.

Kemudian terbitlah Putusan Mahkamah Konstitusi Nomor 18/PUU-XVII/2019. Dalam Putusan Mahkamah Konstitusi Nomor 18/PUU-XVII/2019 menyatakan bahwa Pasal 15 ayat (2) UU Jaminan Fidusia sepanjang frasa "kekuatan eksekutorial" dan frasa "sama dengan putusan pengadilan yang berkekuatan hukum tetap" bertentangan dengan Undang-Undang Dasar Indonesia Tahun 1945 (selanjutnya disebut UUD 1945) dan tidak mempunyai kekuatan hukum mengikat sepanjang tidak dimaknai "terhadap jaminan fidusia yang tidak ada kesepakatan tentang cidera janji atau wanprestasi dan debitur keberatan menyerahkan secara sukarela obyek yang menjadi obyek jaminan fidusia, maka segala mekanisme dan prosedur hukum dalam pelaksanaan eksekusi sertifikat jaminan fidusia harus dilakukan dan berlaku sama dengan pelaksanaan eksekusi putusan pengadilan yang telah berkekuatan hukum tetap".

Dalam putusan Mahkamah Konstitusi tersebut juga menyatakan terhadap frasa "cidera janji" sebagaimana diatur dalam Pasal 15 ayat (3) UU Jaminan Fidusia bertentangan dengan UUD 1945 dan tidak mempunyai kekuatan hukum mengikat sepanjang tidak dimaknai bahwa "adanya cidera janji tidak ditentukan secara sepihak oleh kreditur melainkan atas dasar kesepakatan antara kreditur dengan debitur atau atas dasar upaya hukum yang menentukan telah terjadinya cidera janji”. Namun putusan Mahkamah Konstitusi tersebut menimbulkan akibat hukum bagi notaris dalam pembuatan akta jaminan fidusia. 


\section{B. Rumusan Masalah}

1. Apa karakteristik jaminan fidusia menurut Peraturan Perundang-Undangan di Negara Republik Indonesia?

2. Apa akibat hukum bagi notaris dalam pembuatan akta jaminan fidusia pasca terbitnya Putusan Mahkamah Konstitusi Nomor 18/PUU-XVII/2019 tentang eksekusi jaminan fidusia?

\section{Metode Penelitian}

Penelitian ini merupakan penelitian hukum normatif, yaitu metode pendekatan melalui pengkajian terhadap asas-asas hukum dan sistematika hukum yang ada dalam peraturan perundang-undangan yang berlaku, sehingga penelitian secara normatif ini dapat fokus pada inventarisasi hukum positif. Penelitian ini juga mengunakan pendekatan perundang-undangan (statute approach) dan pendekatan konseptual (conceptual approach). Pendekatan perundang-undangan (statute approach) adalah pendekatan dengan menelaah semua peraturan perundangundangan dan regulasi yang berhubungan satu sama lain dengan permasalahan yang dibahas. Pendekatan konseptual (conceptual approach) adalah pendekatan yang dilakukan dengan dasar pandangan-pandangan dan doktrin-doktrin yang berkembang dan ilmu hukum terkait. ${ }^{9}$

\section{Hasil Penelitian Dan Pembahasan}

\section{Karakteristik Jaminan Fidusia menurut Peraturan Perundang-Undangan di Negara Republik Indonesia}

Pada saat ini, jaminan fidusia adalah suatu jaminan utang yang bersifat kebendaan (baik utang yang telah ada maupun utang yang akan ada), yang pada prinsipnya memberikan benda bergerak sebagai jaminannya (tetapi dapat juga diperluas terhadap benda-benda tidak bergerak) dengan memberikan penguasaan dan penikmatan atas benda tersebutkepada kreditor) kemudian pihak kreditor menyerahkan kembali penguasaan dan penikmatan atas benda tersebut kepada debitornya secara kepercayaan (fiduciary). ${ }^{10}$

Jaminan fidusia menurut A.Hamzah dan Senjun Manulang, jaminan fidusia adalah suatu cara pengoperan hak milik dari pemiliknya (debitor), berdasarkan adanya perjanjian pokok (perjanjian utang piutang) kepada kreditor, akan tetapi

\footnotetext{
${ }^{9}$ Peter Mahmud Marzuki, (2011), Penelitian Hukum, Jakarta: Kencana Prenamedia Group, h.

${ }^{10}$ Munir Fuady, (2000), Hukum Jaminan Utang, Jakarta: Erlangga, h.102.
} $18-19$. 
yang diserahkan hanya haknya saja secara yuridis-levering dan hanya dimiliki oleh kreditor secara kepercayaan saja (sebagai jaminan utang debitor), sedangkan bendanya tetap dikuasai oleh debitor, tetapi bukan lagi sebagai eigeenar maupun bezitter, melainkan hanya sebagai detentor atau houder dan atas nama kreditor-eigenaar. ${ }^{11}$

Definisi jaminan fidusia diatur dalam Pasal 1 angka 2 Undang-Undang Nomor 42 tahun 1999 tentang Jaminan Fidusia adalah hak jaminan atas benda bergerak baik yang berwujud maupun yang tidak berwujud dan benda tidak bergerak khususnya bangunan yang tidak dapat dibebani hak tanggungan sebagaimana dimaksud dalam Undang-Undang Nomor 4 Tahun 1996 tentang Hak Tanggungan yang tetap berada dalam penguasaan Pemberi Fidusia, sebagai aguna bagi pelunasan utang tertentu, yang memberikan kedudukan yang diutamakan kepada Penerima Fidusia terhadap kreditor lainnya. ${ }^{12}$

Jaminan Fidusia yang diatur dalam UU Jaminan Fidusia mempunyai sifatsifat sebagai berikut: ${ }^{13}$

a. Jaminan Fidusia mempunyai sifat accesoir, sebagaimana ditegaskan dalam Pasal 4 UU Jaminan Fidusia ialah hak kebendaan akan tetap mengikuti benda ke tangan siapapun benda tersebut berada.

b. Jaminan Fidusia adalah hak kebendaan sebagaimana tercermin pada:

1) Pasal 20 UU Jaminan Fidusia yaitu asas droit de suite. Asas droit de suite hanya berlaku pada benda bukan persediaan. Untuk benda persediaan tidak berlaku asas droit de suite.

2) Pasal 1 angka 2 UU Jaminan Fidusia yaitu asas droit de preference bahwa kedudukan kreditor pemegang jaminan fidusia adalah berkedudukan sebagai kreditor konkuren.

3) Pasal 27 ayat (1) jo. Pasal 28 UU Jaminan Fidusia yaitu asas prioritas bahwa hak kebendaan yang ada terlebih dahulu akan diutamakan daripada hak kebendaan yang lahir kemudian.

c. Jaminan fidusia menjamin utang yang telah ada, utang yang akan timbul dikemudian hari, utang yang pada saat eksekusi dapat ditentukan jumlahnya berdasarkan perjanjian pokok yang menimbulkan kewajiban memenuhi suatu prestasi pada Pasal 7 UU Jaminan Fidusia.

${ }^{11}$ Salim HS, (2012), Perkembangan Hukum Jaminan di Indonesia, Jakarta: Rajawali Pers, h. 55.

12 Trisadini Prasastinah Usanti dan Lenonora Bakarbessy, (2014), Buku Referensi Hukum Perbankan Hukum Jaminan, Surabaya: Revka Petra Media, h. 118.

${ }^{13}$ Ibid., h. 119. 
d. Jaminan fidusia dapat menjamin lebih dari satu utang, sebagaimana diatur pada Pasal 8 UU Jaminan Fidusia.

e. Eksekusi jaminan fidusia diatur dalam Pasal 29 UU Jaminan Fidusia.

f. Penerima Fidusia sebagai kreditor separatis dalam hal kepailitan sebagaimana diatur pada Pasal 27 ayat (3) UU Jaminan Fidusia.

Obyek jaminan fidusia diatur dalam pasal 1 angka 2, Pasal 2, Pasal 1 angka 4, Pasal 3, Pasal 9 Undang-Undang Nomor 42 tahun 1999 tentang Jaminan fidusia serta Pasal 48 Undang-Undang Nomor 20 Tahun 2011 tentang Rumah Susun. ${ }^{14}$ Obyek jaminan fidusia berupa benda bergerak baik yang berwujud maupun yang tidak berwujud dan benda bergerak khususnya bangunan yang tidak dapat dibebani hak tanggungan. ${ }^{15}$

Tahapan pembebanan jaminan fidusia didasarkan pada beberapa dasar hukum yakni : Undang-Undang Nomor 2 Tahun 2014 tentang perubahan atas Undang-Undang Nomor 30 Tahun 2004 tentang Jabatan Notaris (UUJN); Undang-Undang Nomor 42 Tahun 1999 tentang Jaminan Fidusia; Peraturan Pemerintah Nomor 21 Tahun 2015 tentang Tata Cara Pendaftaran Jaminan Fidusia dan Biaya Pembuatan Akta Jaminan Fidusia.; Peraturan Hukum dan Hak Asasi Manusia Nomor 10 Tahun 2013 tentang Tata Cara Pendaftaran Jaminan Fidusia Secara Elektronik.

Adapun tahap-tahap pengikatan (pembebanan) jaminan Fidusia sebagaimana dimaksud adalah sebagai berikut:

a. Tahap Pertama (Pembuatan Perjanjian Pokok): ${ }^{16}$

1) Tahap pertama didahului dengan dibuatnya perjanjian pokok yang berupa perjanjian kredit atau perjanjian utang. Perjanjian pokok yang berupa perjanjian kredit dapat dibuat dengan akta di bawah tangan artinya dibuat oleh Kreditor dan Debitor sendiri atau akta otentik artinya dibuat oleh dan di hadapan Notaris

2) Didahuluinya pembuatan perjanjian pokok yang berupa perjanjian kredit ini sesuai sifat accessoir dari jaminan fidusia yang artinya pembebanan jaminan fidusia merupakan ikutan dari perjanjian pokok. Pasal 4 UU Jaminan fidusia menegaskan jaminan fidusia merupakan

${ }^{14}$ Ibid., h. 118

${ }^{15}$ Ibid., h. 157.

${ }^{16}$ Fani Martiawan Kumara Putra, (2016), Karakteristik Pembebanan Jaminan Fidusia pada Benda Persediaan dan Penyelesaian Sengketa saat Debitor Wanprestasi. Jurnal Prespektif Volume XXI No. 1 Tahun 2016 Edisi Januari, Fakultas Hukum Universitas Wijaya Kusuma Surabaya, h. 39. 
perjanjian ikutan dari suatu perjanjian pokok yang menimbulkan kewajiban bagi para pihak untuk memenuhi suatu prestasi

3) Perjanjian jaminan sebagai perjanjian ikutan (tambahan) dimaksudkan untuk mendukung secara khusus perjanjian terdahulu yaitu perjanjian pokok (perjanjian kredit) yang telah disepakati dan yang hanya memiliki sifat relatif.

\section{b. Tahap Kedua (Pembuatan Akta Jaminan Fidusia):}

1) Tahap kedua berupa pembebanan benda dengan jaminan fidusia yang ditandai dengan pembuatan Akta Jaminan Fidusia yang ditandatangani oleh Kreditor sebagai penerima fidusia dan Debitor sebagai pemberi Fidusia atau pemilik benda tetapi bukan debitor. Dalam Akta Jaminan Fidusia juga dicantumkan hari, tanggal pembuatan dan waktu atau jam pembuatan akta tersebut

2) Pembebanan fidusia dibuat dalam Bentuk Akta Jaminan Fidusia adalah akta otentik yang dibuat oleh dan dihadapan Notaris dengan judul "Akta Jaminan Fidusia".

3) Akta jaminan fidusia ini haruslah dibuat dengan akta Notaris (Pasal 5 ayat (1) Undang-Undang Nomor 42 Tahun 1999 Jaminan Fidusia). Apabila akta jaminan fidusia hanya dibuat dibawah tangan, maka akibat hukumnya penerima fidusia/kreditor hanya berkedudukan sebagai kreditor konkuren, bukan sebagai kreditor preferen karena tidak pernah lahir jaminan fidusia.

4) Akta Jaminan Fidusia menunjukkan asas spesialitas. Asas ini tercermin dalam Pasal 6 UU Jaminan Fidusia. Akta jaminan Fidusia memuat halhal sebagai berikut:

I. Identitas pihak pemberi Fidusia, yakni: Nama lengkap, Tempat tinggal atau tempat kedudukan, Tempat dan Tanggal lahir, Jenis kelamin, Status perkawinan, Agama, Pekerjaan. Identitas pihak pemberi fidusia harus sesuai dengan Kartu Tanda Penduduk milik pemberi fidusia tersebut.

II. Mencantumkan hari, tanggal dan jam pembuatan akta Fidusia.

III. Data perjanjian pokok yang dijamin dengan Fidusia;

IV. Uraian mengenai benda yang menjadi objek jaminan Fidusia, yakni tentang identifikasi benda tersebut, dan surat bukti kepemilikannya. Jika bendanya selalu berubah-ubah seperti benda dalam persediaan (inventory), haruslah disebutkan tentang jenis, merek, dan kualitas dari benda tersebut;

V. Nilai penjaminannya; 
VI. Nilai benda yang menjadi objek jaminan Fidusia.

5) Biaya Pembuatan Akta Jaminan Fidusia diatur dalam Pasal 18 Peraturan Pemerintah Nomor 21 Tahun 2015 tentang Tata Cara Pendaftaran Jaminan Fidusia dan Biaya Pembuatan Akta Jaminan Fidusia yang berbunyi sebagai berikut: "Pembuatan akta Jaminan Fidusia dikenakan biaya yang besarnya ditentukan berdasarkan nilai penjaminan, dengan ketentuan sebagai berikut:" I. nilai penjaminan sampai dengan Rp100.000.000,00 (seratus juta rupiah), biaya pembuatan akta paling banyak 2,5\% (dua koma lima perseratus); II. nilai penjaminan di atas Rp100.000.000,00 (seratus juta rupiah) sampai dengan Rp1.000.000.000,00, (satu miliar rupiah), biaya pembuatan akta paling banyak $1,5 \%$ (satu koma lima perseratus); dan III. nilai penjaminan di atas Rp1.000.000.000,00 (satu miliar rupiah), biaya pembuatan akta berdasarkan kesepakatan antara notaris dengan para pihak, tetapi tidak melebihi $1 \%$ (satu perseratus) dari objek yang dibuatkan aktanya

\section{c. Tahap Ketiga yaitu Pendaftaran Jaminan Fidusia diatur dalam:}

1. Pasal 2 sampai Pasal 10 Peraturan Pemerintah Nomor 21 Tahun 2015 tentang Tata Cara Pendaftaran Jaminan Fidusia dan Biaya Pembuatan Akta Jaminan Fidusia.

2. Pasal 2 dan Pasal 3 Peraturan Hukum dan Hak Asasi Manusia Nomor 10 Tahun 2013 tentang Tata Cara Pendaftaran Jaminan Fidusia Secara Elektronik.

Berkenaan dengan ketentuan eksekusi jaminan fidusia diatur dalam Pasal 15 juncto Pasal 29 UU Jaminan Fidusia. Dalam Pasal tersebut, memberikan kemudahan bagi kreditor untuk menyelesaikan kreditnya tidak harus dengan mengajukan gugatan ke pengadilan negeri tetapi kreditor dapat melakukan eksekusi dengan cara sebagai berikut: ${ }^{17}$ Pasal 15 ayat (1), ayat (2) dan ayat (3) UU Jaminan Fidusia menyatakan bahwa dalam Sertifikat Jaminan Fidusia dicantumkan kata-kata "DEMI KEADILAN BERDASARKAN KETUHANAN YANG MAHA ESA" yang mana Sertifikat Jaminan Fidusia tersebut mempunyai kekuatan eksekutorial yang sama dengan putusan pengadilan yang telah memperoleh kekuatan hukum tetap. Dan apabila debitor cidera janji, Penerima Fidusia mempunyai hak untuk menjual Benda yang menjadi obyek Jaminan Fidusia atas kekuasaannya sendiri.

Dalam Pasal 15 terkandung makna 2 (dua) cara eksekusi yaitu : ${ }^{18}$

${ }^{17}$ Ibid., h. 133.

${ }^{18}$ Ibid, Op.Cit., h. 134. 
a. Eksekusi dengan menggunakan titel eksekutorial adalah langsung dapat dilaksanakan melalui pengadilan dibawah pimpinan ketua Pengadilan Negeri atau harus ada fiat eksekusi dari ketua Pengadilan Negeri karena sertifikat fidusia dianggap sama dengan putusan pengadilan yang mempunyai kekuatan hukum tetap (in kracht van gewijsde) dan bersifat final serta mengikat para pihak untuk melaksanakan putusan tersebut.

b. Parate Eksekusi, salah satu ciri dari jaminan kebendaan adanya parate eksekusi yaitu kemudahan dalam melaksanakan eksekusi apabila debitor wanprestasi.

Selanjutnya dalam Pasal 29 ayat (1) dan ayat (2) UU Jaminan Fidusia yang menyatakan bahwa, "Apabila debitur atau Pemberi Fidusia Cidera Janji, eksekusi terhadap benda yang menjadi obyek jaminan fidusia dapat dilakukan dengan cara : a. pelaksanaan titel eksekutorial sebagaimana dimaksud dalam Pasal 15; b. penjualan benda yang menjadi obyek Jaminan Fidusia atas kekusaan penerima fidusia sendiri melalui pelelangan umum serta mengambil pelunasan piutangnya dari hasil penjualan

Penjualan dibawah tangan yang dilakukan berdasarkan kesepakatan Pemberi dan Penerima Fidusia jika dengan cara demikian dapat diperoleh harga tertinggi yang menguntungkan para pihak. Pelaksanaan penjualan dilakukan setelah lewat waktu 1 (satu) bulan sejak diberitahukan secara tertulis oleh Pemberi dan atau Penerima Fidusia kepada pihak-pihak yang berkepentingan dan diumumkan sedikitnya dalam 2 (dua) surat kabar yang beredar di daerah yang bersangkutan.

Hapusnya suatu jaminan fidusia diatur dalam Pasal 25 Undang-Undang Nomor 42 Tahun 1999 tentang Jaminan Fidusia, Pasal 16 dan Pasal 17 Peraturan Pemerintah Nomor 21 Tahun 2015 tentang Tata Cara Pendaftaran Jaminan Fidusia dan Biaya Pembuatan Akta Jaminan Fidusia, Pasal 6 ayat (3) Peraturan Menteri Hukum dan Hak Asasi Manusia nomor 10 Tahun 2013 tentang Tata Cara Pendaftaran Jaminan Fidusia secara Elektronik.

Menurut Pasal 25 Undang-Undang Nomor 42 Tahun 1999 tentang Jaminan Fidusia alasan dihapusnnya jaminan fidusia dikarenakan hal-hal sebagai berikut: a. hapusnya utang yang dijamin dengan fidusia; b. pelepasan hak atas Jaminan Fidusia oleh Penerima Fidusia; atau c. musnahnya benda menjadi obyek Jaminan Fidusia dimana musnahnya benda yang menjadi obyek Jaminan Fidusia tidak menghapuskan klaim asuransi sesuai ketentuan.

Penerima Fidusia memberitahukan kepada Kantor Pendaftaran Fidusia mengenai hapusnya Jaminan Fidusia dengan melampirkan pernyataan mengenai hapusnya utang, pelepasan hak atau musnahnya benda yang menjadi obyek Jaminan Fidusia tersebut. 
Sedangkan dalam Pasal 16 Peraturan Pemerintah Nomor 21 Tahun 2015 tentang Tata Cara Pendaftaran Jaminan Fidusia dan Biaya Pembuatan Akta Jaminan Fidusia alasan jaminan fidusia dihapuska sama dengan ketentuan undang-undang, Namun, terdapat ketentuan khusus dimana Penerima Fidusia, kuasa atau wakilnya, wajib memberitahukan kepada Menteri dalam jangka waktu paling lama 14 (empat belas) hari terhitung sejak tanggal hapusnya Jaminan Fidusia. Pemberitahuan penghapusan Jaminan Fidusia sebagaimana dimaksud pada ayat (2) paling sedikit memuat: a. keterangan atau alasan hapusnya Jaminan Fidusia; b. nomor dan tanggal sertifikat Jaminan Fidusia;c. nama dan tempat kedudukan notaris; dand. tanggal hapusnya Jaminan Fidusia.

Selanjutnya dalam Pasal 17 Peraturan Pemerintah Nomor 21 Tahun 2015 tentang Tata Cara Pendaftaran Jaminan Fidusia dan Biaya Pembuatan Akta Jaminan Fidusia diatur menngenai proses setelah adanya pemerintahan. Berdasarkan pemberitahuan penghapusan, Jaminan Fidusia dihapus dari daftar Jaminan Fidusia dan diterbitkan keterangan penghapusan yang menyatakan sertifikat Jaminan Fidusia yang bersangkutan tidak berlaku lagi. Tetapi,jika Penerima Fidusia, kuasa atau wakilnya tidak memberitahukan penghapusan Jaminan Fidusia, Jaminan Fidusia yang bersangkutan tidak dapat didaftarkan kembali.

Seiring perkembangan elekronik untuk penghapusan jaminan fidusia secara elektronik diatur dalam Peraturan Menteri Hukum dan Hak Asasi Manusia nomor 10 Tahun 2013 tentang Tata Cara Pendaftaran Jaminan Fidusia secara Elektronik dimana permohonan penghapusan jaminan fidusia dilampiri: ${ }^{19}$ a. Surat keterangan lunas yang berasal dari penerima fidusia atau surat keterangan pelepasan hak atau surat keterangan musnahnya obyek jaminan fidusia; b. Sertifikat jaminan fidusia; dan c. Bukti pembayaran biaya penghapusan sertifikat jaminan fidusia sesuai dengan ketentuan peraturan perundangundangan.

Dalam hal pemohon telah melakukan pembayaran biaya penghapusan sertifikat jaminan fidusia, kantor pendaftaran fidusia menerbitkan surat keterangan yang menyatakan sertifikat jaminan fidusia tidak berlaku lagi.

2. Perbedaan antara Eksekusi Jaminan Fidusia dalam Undang-Undang Nomor 42 tahun 1999 tentang Jaminan Fidusia dengan Eksekusi Jaminan Fidusia dalam Putusan Mahkamah Konstitusi Nomor 18/PUU-XVII/2019 dan Akibat Hukum Bagi Notaris dalam Pembuatan Akta Jaminan Fidusia

\footnotetext{
${ }^{19}$ Ibid., h. 136.
} 
Eksekusi jaminan fidusia sebagaimana yang diatur dalam BAB V UndangUndang Nomor 42 Tahun 1999 sebagaimana bunyi Pasal 29 Undang-Undang Jaminan Fidusia menyebutkan, "dalam hal debitor Pemberi Fidusia cidera janji maka kreditor Penerima Fidusia yang telah mempunyai/memegang Sertipikat Fidusia dapat/berhak untuk menjual objek Jaminan Fidusia dengan cara : memohon eksekusi sertipikat yang berjudul Demi Keadilan Berdasarkan Ketuhanan Yang Maha Esa; menjual objek jaminan fidusia atas kekuasaan sendiri melalui pelelangan umum serta mengambil pelunasan piutang dari hasil penjualan; menjual objek jaminan fidusia dibawah tangan yang dilakukan berdasarkan kesepakatan pemberi dan penerima fidusia jika dengan cara ini akan diperoleh harga yang tertinggi sehingga menguntungka para pihak. Penjualan bawah tangan ini dilakukan setelah lewat waktu 1 (satu) bulan sejak diterbitkannya secara tertulis oleh pemberi dan atau penerima fidusia kepada pihak - pihak yang berkepentingan dan diumumkan sedikitnya dalam 2 (dua) surat kabar yang beredar di daerah yang bersangkutan. ${ }^{20}$

a. Pelaksanaan titel eksekusi

Dalam sertipikat jaminan fidusia yang diterbitkan Kantor Pendaftaran Fidusia dicantumkan kata-kata Demi Keadilan Berdasarkan Ketuhanan Yang Maha Esa. Sertipikat jaminan fidusia ini mempunyai kekuatan eksekutorial yang sama dengan putusan pengadilan yang telah memperoleh kekuatan hukum yang tetap. Yang dimaksud dengan kekuatan eksekutorial adalah langsung dapat dilaksanakan eksekusi tanpa melalui pengadilan dan bersifat final serta mengikat para pihak untuk melaksanakan putusan tersebut. ${ }^{21}$

Ada 2 (dua) syarat utama dalam pelaksanaan titel eksekusi (atas hak eksekusi) oleh penerima fidusia, yakni $:^{22}$

1) Debitor atau pemberi fidusia cidera janji;

2) Ada sertipikat jaminan fidusia yang mencantumkan irah-irah Demi Keadilan Berdasarkan Ke-Tuhanan Yang Maha Esa.

Pada pelaksanaan titel eksekusi tidak dijelaskan atau dicantumkan apakah pelaksanaan eksekusi tersebut dengan lelang atau dibawah tangan, namun mengingat sifat eksekusi dan mengingat penjualan secara di bawah tangan telah $^{23}$ diberi persyaratan berdasarkan kesepakatan pemberi dan penerima fidusia, maka pelaksanaan titel eksekusi haruslah dengan cara lelang.

${ }^{20}$ Rexy Rionaldi Refri, (2018), Akibat Hukum Perjanjian Fidusia yang Dibuat dengan Akta Dibawah Tangan, Jurnal Notaire: Vol. 1 No. 1, Juni 2018, Magister Kenotariatan Universitas Airlangga, h. 127.

${ }^{21}$ Ibid.

${ }^{23}$ Ibid. 
b. Penjualan atas kekuasaan penerima fidusia

Dalam hal debitor cidera janji, penerima fidusia mempunyai hak untuk menjual benda objek jaminan fidusia atas kekuasaannya sendiri. Penjualan dengan cara ini dikenal dengan lembaga parate eksekusi dan diharuskan dilakukan penjualan di muka umum (lelang). Dengan demikian Parate Eksekusi kurang lebih adalah kewenangan yang diberikan (oleh undang-undang atau putusan pengadilan) kepada salah satu pihak untuk melaksanakan sendiri secara paksa isi perjanjian dalam hal pihak yang lainnya (debitor) ingkar janji (wanprestasi). Kekuasaan untuk pelaksanaan ini harus dibuktikan dengan sertipikat jaminan fidusia dan secara otomatis eksekusi atas kekuasaan sendiri (parate eksekusi) ini mengandung persyaratan yang sama dengan eksekusi atas alas hak eksekusi (titel eksekusi). ${ }^{24}$

c. Penjualan di bawah tangan

Pelaksanaan eksekusi jaminan dengan cara penjualan di bawah tangan merupakan suatu perkembangan dalam sistem eksekusi yang sebelumnya juga telah dianut dalam eksekusi Hak Tanggungan atas Tanah (UU No. 4 Tahun 1996). Seperti halnya dalam Undang-Undang Hak Tanggungan maka UndangUndang Fidusia ini penjualan di bawah tangan objek fidusia juga mengandung beberapa persyaratan yang relatif berat untuk dilaksanakan. Ada 3 (tiga) persyaratan untuk dapat melakukan penjualan di bawah tangan: ${ }^{25}$ 1) Kesepakatan pemberi dan penerima fidusia. Syarat ini diperkirakan akan berpusat pada soal harga dan biaya yang menguntungkan para pihak; 2) Setelah lewat waktu 1 (satu) bulan sejak diberitahukan secara tertulis oleh pemberi dan atau penerima fidusia kepada pihak-pihak berkepentingan; 3)Diumumkan sedikitnya 2 (dua) surat kabar yang beredar di daerah yang menguntungkan.

Eksekusi Jaminan Fidusia Pasca Putusan Mahkamah Konstitusi Nomor 18/PUU-XVII/2019 dilakukan pada saat adanya kesepakatan mengenai wanprestasi dan kerelaan debitur untuk menyerahkan benda yang menjadi obyek fidusia. Apabila tidak terdapat kesepakatan mengenai wanprestasi dan debitur tidak menyerahkan obyek jaminan secara sukarela, maka prosedur eksekusi jaminan fidusia dilakukan sama dengan eksekusi putusan pengadilan yang telah berkekuatan hukum tetap, yaitu dengan mengajukan permohonan eksekusi ke Pengadilan Negeri. Selain itu, wanprestasi juga tidak dapat ditentukan sepihak. Harus ada kesepakatan mengenai wanprestasi yang ditentukan oleh kedua belah pihak atau atas dasar upaya hukum /gugatan yang menyatakan bahwa salah satu pihak telah melakukan wanprestasi.

Sebelum memasuki pembahasan berkenaan akibat hukum bagi notaris dalam pembuatan akta jaminan fidusia pasca terbitnya Putusan Mahkamah

${ }^{24}$ Rexy Rionaldi Refri, Op.Cit., h. 128.

${ }^{25}$ Ibid. 
Konstitusi Nomor 18/PUU-XVII/2019 tentang Eksekusi Jaminan Fidusia. Perlu dipahami terlelbih dahulu definisi dan kewenangan dari Notaris. Menurut G.H.S. Lumban Tobing, wewenang utama notaris yaitu untuk membuat akta otentik. Otentisitas dari akta notaris bersumber dari Pasal 1 Peraturan Jabatan Notaris dimana notaris dijadikan sebagai "pejabat umum", sehingga akta yang dibuat oleh notaris karena kedudukannya tersebut memperoleh sifat sebagai akta otentik. $^{26}$ Notaris menurut Pasal 1 ayat (1) Undang-Undang Nomor 2 Tahun 2014 tentang perubahan atas Undang-Undang Nomor 30 Tahun 2004 tentang Jabatan Notaris (selanjutnya disebut UUJN) adalah pejabat umum yang berwenang untuk membuat akta autentik dan memiliki kewenangan lainnya sebagaimana dimaksud dalam undang-undang ini atau berdasarkan undangundang lainnya. ${ }^{27}$

Kewenangan Notaris diatur dalam Pasal 15 dari ayat (1) sampai dengan ayat (3) UUJN, dibagi menjadi : a. Kewenangan Umum Notaris. Pasal 15 ayat (1) UUJN menegaskan bahwa salah satu kewenangan Notaris yaitu membuat akta secara umum dengan batasan sepanjang: 1) Tidak dikecualikan kepada pejabat lain yang telah ditetapkan oleh undang-undang. 2) Akta yang harus dibuat adalah akta otentik mengenai semua perbuatan, perjanjian dan ketetapan yang diharuskan oleh aturan hukum untuk dibuat atau dikehendaki oleh yang bersangkutan; 3) Kepentingan subjek hukumnya yaitu harus jelas untuk kepentingan siapa suatu akta itu dibuat; 4) Akta otentik yang merupakan wewenang Notaris dan juga menjadi wewenang pejabat atau instansi lain, yaitu: Akta pengakuan anak di luar kawin (Pasal $281 \mathrm{BW}$ ), Akta berita acara tentang kelalaian pejabat penyimpan hipotik (Pasal 1227 BW), Akta berita acara tentang penawaran pembayaran tunai dan konsinyasi (Pasal 1405, 1406 BW), Akta protes wesel dan cek (Pasal 143 dan $218 \mathrm{WvK}$ ), Surat kuasa membebankan Hak Tanggungan (Pasal 15 ayat [1] UU No.4 Tahun 1996).

Berdasarkan wewenang yang ada pada Notaris sebagaimana tersebut dalam Pasal 15 UUJN dan kekuatan pembuktian dari akta Notaris, maka ada 2 hal yang dapat kita pahami, yaitu: Notaris dalam tugas jabatannya memformulasikan keinginan/tindakan para pihak ke dalam akta otentik, dengan memperhatikan aturan hukum yang berlaku; Akta Notaris sebagai akta otentik mempunyai kekuatan pembuktian yang sempurna, sehingga tidak perlu dibuktikan atau ditambah dengan alat bukti yang lainnya.

Notari memiliki kewenangan khusus yakni melakukan tindakan hukum tertentu, seperti: 1) Mengesahkan tanda tangan dan menetapkan kepastian tanggal surat di bawah tangan dengan mendaftarkannya di dalam suatu buku khusus; 2)

\footnotetext{
${ }^{26}$ G.H.S. Lumban Tobing, (2012), Peraturan Jabatan Notaris, Cetakan ke 4, Jakarta: Erlangga, , h.48.

${ }^{27}$ Ghansham Anand, (2014), Karakteristik Jabatan Notaris di Indonesia, Sidoarjo: Zifatama Publisher, h. 36.
} 
Membukukan surat-surat di bawah tangan dengan mendaftarkannya dalam suatu buku khusus; 3) Membuat salinan (copy) asli dari surat-surat di bawah tangan berupa salinan yang memuat uraian sebagaimana ditulis dan digambarkan dalam surat yang bersangkutan; 4) Melakukan pengesahan kecocokan antara fotokopi dengan surat aslinya; 5) Memberikan penyuluhan hukum sehubungan dengan pembuatan akta; 6) Membuat akta yang berkaitan dengan pertanahan, atau 7) Membuat akta risalah lelang.

Berdasarkan Pasal 5 ayat 1 Undang-Undang Jaminan Fidusia yang menyatakan "Pembebanan benda dengan jaminan fidusia dibuat dengan akta Notaris dalam Bahasa Indonesia dan merupakan akta Jaminan Fidusia" Pada hakikatnya pembuatan serta pendaftaran fidusia tersebut merupakan perwujudan dari asas publisitas. Asas publikasi atau Asas publisitas ini dapat memberikan kepastian hukum yang diatur dalam Pasal 11 ayat (1) UndangUndang Nomor 42 Tahun 1999 yang menyatakan bahwa benda yang dibebani dengan Jaminan Fidusia wajib didaftarkan. Pengaturan asas publikasi juga diatur dalam ketentuan Pasal 12 juncto Pasal 18 UU Jaminan Fidusia.

Bahwa pasca terbitnya Putusan Mahkamah Konstitusi Nomor 18/PUUXVII/2019, dalam jaminan fidusia tetap melekat kekuatan eksekutorial yang sama dengan putusan pengadilan yang telah mempunyai kekuatan hukum tetap dan kreditur sebagai penerima jaminan fidusia tetap memiliki kewenangan penuh untuk dapat melakukan eksekusi sendiri secara langsung (parate eksekusi), sepanjang debitur sebagai pemberi fidusia "cidera janji" atau wanprestasi baik yang diakui oleh debitur maupun berdasarkan upaya hukum dan "tidak ada keberatan menyerahkan secara sukarela obyek jaminan fidusia". Parate eksekusi jaminan fidusia harus dilakukan setelah terjadinya cidera janji atau wanprestasi sebagaimana ditentukan dalam perjanjian kredit atau perjanjian utang piutang. Apabila didalam perjanjian kredit tersebut tidak mengatur bentuk cidera janji atau wanprestasi, maka bentuk wanprestasi mengacu pada pasal 1238 Burgelijk Wetboek yang menyatakan: "Bahwa Jika Debitur lalai dengan lewatnya waktu memenuhi pembayaran dan kreditur telah menyampaikan surat perintah kepada debitur untuk membayar". Jika eksekusi jaminan fidusia harus dilakukan melalui proses pengadilan, maka dapat menghilangkan kekhususan jaminan fidusia yang diatur dalam Pasal 15 ayat (3) Undang-Undang Nomor 42 tahun 1999 tentang Jaminan Fidusia yaitu kemudahan dalam pelaksanaan eksekusi. Cidera janji atau wanprestasi merupakan faktor yang sangat penting dalam eksekusi jaminan fidusia. Oleh karena itu, dalam kaitannya dengan kewenangan notaris dalam pembuatan akta jaminan fidusia, maka notaris harus mengubah akta jaminan fidusia yang selama ini dibuat dengan cara notaris harus menambahkan dan memperjelas klausula wanprestasi atau cidera janji secara terperinci yang terdiri dari definisi, bentuk-bentuk, bagaimana dan kapan wanprestasi atau cidera janji. Notaris juga harus mencantumkan klausula penyerahan sukarela tentang obyek jaminan 
fidusia yang terdiri dari bagaimana pemberi jaminan fidusia tidak bersedia menyerahkan jaminan fidusia secara sukarela dan bagaimana penerima jaminan fidusia apabila akan melakukan upaya paksa. Tujuan dari Notaris harus menambahkan dan memperjelas klausula wanprestasi atau cidera janji secara terperinci serta mencantumkan klausula penyerahan sukarela tentang obyek jaminan fidusia dalam akta jaminan fidusia adalah untuk menciptakan kepastian hukum dan keadilan bagi kreditor selaku Penerima Fidusia dan Debitor selaku Pemberi Fidusia, karena akta jaminan fidusia wajib mewujudkan perlindungan hukum bagi para pihak dan obyek yang menjadi jaminan fidusia dalam akta jaminan fidusia.

\section{E. Penutup}

Eksekusi jaminan fidusia diatur dalam Pasal 29 UU Jaminan Fidusia. Akibat hukum Pasca terbitnya Putusan Mahkamah Konstitusi Nomor 18/PUU-XVII/2019 tentang Eksekusi Jaminan Fidusia bagi notaris dalam pembuatan akta jaminan fidusia bahwa notaris harus mengubah akta jaminan fidusia yang selama ini dibuat dengan cara notaris harus menambahkan dan memperjelas klausula wanprestasi atau cidera janji secara terperinci yang terdiri dari definisi, bentuk-bentuk, bagaimana dan kapan wanprestasi atau cidera janji. Notaris juga harus mencantumkan klausula penyerahan sukarela tentang obyek jaminan fidusia yang terdiri dari bagaimana pemberi jaminan fidusia tidak bersedia menyerahkan jaminan fidusia secara sukarela dan bagaimana penerima jaminan fidusia apabila akan melakukan upaya paksa.

\section{Daftar Pustaka}

\section{Buku}

Abdulkadir Muhammad dan Rilda Murniati, (2000), Segi Hukum Lembaga Keuangan dan Pembiayaan, Bandung: Citra Aditya Bakti.

Ahmadi Miru, (2007), Hukum Kontrak dan Perancangan Kontrak, Jakarta: Rajawali Pers.

Andy Hartanto, (2015), .Hukum Jaminan dan Kepailitan, Laksbang Yustisia, Surabaya.

Edy P Soekadi, (1990), Mekanisme Leasing, Jakarta: Ghalia Indonesia.

G.H.S. Lumban Tobing, (2012), Peraturan Jabatan Notaris, Cetakan ke 4, .Jakarta: Erlangga.

Ghansham Anand, (2014), .Karakteristik jabatan Notaris di Indonesia, Sidoarjo: Zifatama Publisher.

Salim HS, (2008), .Pengantar Hukum Perdata Tertulis (BW), Jakarta: Sinar Grafika. 
Salim HS, (2012), .Perkembangan Hukum Jaminan di Indonesia , Jakarta: Rajawali Pers.

Subekti, (2007), .Kitab Undang-Undang Hukum Perdata, Jakarta: Arga Printing.

Subekti \& Tjitrosudibio, (2004), Kitab Undang-undang Hukum Perdata, Jakarta: Pradnya Paramita.

Munir Fuady, (2000), Hukum Jaminan Utang, Jakarta: Erlangga.

Munir Fuady, (1999), Hukum tentang Pembiayaan Dalam Teori dan Praktik (Leasing, Factoring, Modal Ventura, Pembiayaan Konsumen, Kartu Kredit), Bandung: Citra Aditya Bakti.

Peter Mahmud Marzuki, (2011) Penelitian Hukum, Jakarta: Kencana Prenamedia Group.

Trisadini Prasastinah Usanti dan Lenonora Bakarbessy, (2014), Buku Referensi Hukum Perbankan Hukum Jaminan, Surabaya: Revka Petra Media.

\section{Peraturan Perundang-Undangan}

Burgelijk Wetboek

Undang-Undang Dasar Negara Republik Indonesia Tahun 1945.

Undang-Undang Nomor 42 Tahun 1999 tentang Jaminan Fidusia.

Undang-Undang Nomor 2 Tahun 2014 tentang perubahan atas Undang-Undang Nomor 30 Tahun 2004 tentang Jabatan Notaris.

Peraturan pemerintah Nomor 21 Tahun 2015 tentang Tata Cara Pendaftaran Jaminan Fidusia dan Biaya Pembuatan Akta Jaminan Fidusia.

Peraturan Presiden Nomor 9 tahun 2009 tentang Lembaga Pembiayaan.

Peraturan Menteri Hukum dan Hak Asasi Manusia Nomor 9 Tahun 2013 tentang Pendaftaran Jaminan Fidusia Secara Elektronik.

\section{Jurnal}

Fani Martiawan Kumara Putra, (2016), Karakteristik Pembebanan Jaminan Fidusia pada Benda Persediaan dan Penyelesaian Sengketa saat Debitor Wanprestasi. Jurnal Prespektif Volume XXI No. 1 Tahun 2016 Edisi Januari, Fakultas Hukum Universitas Wijaya Kusuma Surabaya, 
Rexy Rionaldi Refri, (2018), Akibat Hukum Perjanjian Fidusia yang Dibuat dengan Akta Dibawah Tangan, Jurnal Notaire: Vol. 1 No. 1, Juni 2018, Magister Kenotariatan Universitas Airlangga.

\section{Putusan Pengadilan}

Putusan Pengadilan Negeri Nomor. 345/PDT.G/2018/PN.Jkt.Sel.

Putusan Mahkamah Konstitusi Nomor 18/PUU-XVII/2019 